
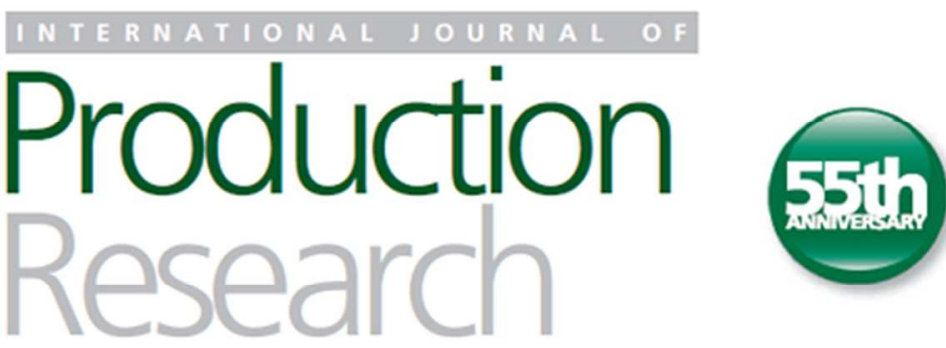

Official Joumal of the Intemational Foundation for Production Research

Editor-in-Chief: Alexandre Dolgui

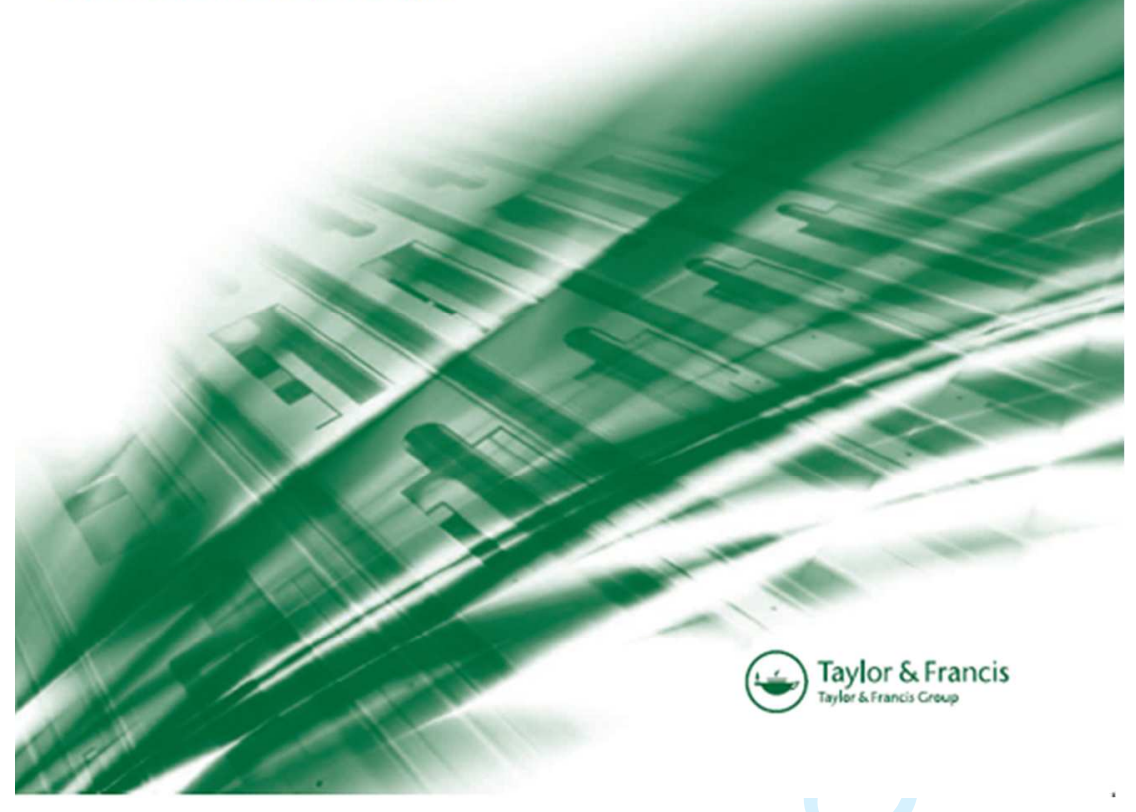

\title{
Investments in big data analytics and firm performance: an empirical investigation of direct and mediating effects
}

\begin{tabular}{|r|l|}
\hline Journal: & International Journal of Production Research \\
\hline Manuscript ID & TPRS-2017-IJPR-0682.R1 \\
\hline Manuscript Type: & Original Manuscript \\
\hline Date Submitted by the Author: & 31 -Aug-2017 \\
\hline Complete List of Authors: & $\begin{array}{l}\text { Raguseo, Elisabetta; Politecnico di Torino, DISPEA } \\
\text { Vitari, Claudio }\end{array}$ \\
\hline
\end{tabular}


Keywords: $\quad$ BIG DATA, PERFORMANCE MEASURES

Keywords (user): 


\section{Title page}

\section{Title}

Investments in big data analytics and firm performance: an empirical investigation of direct and mediating effects

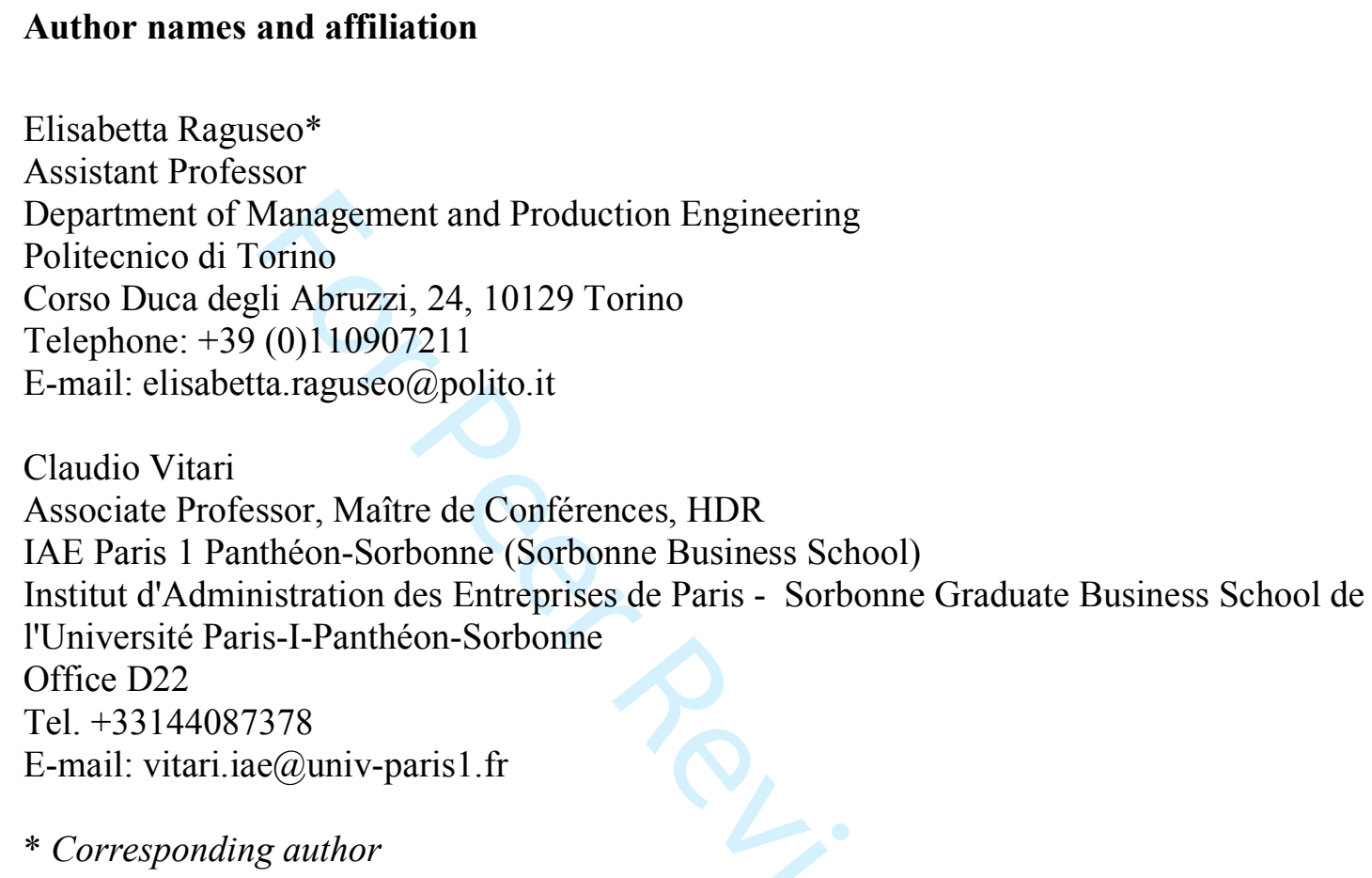




\title{
Investments in big data analytics and firm performance: an empirical investigation of direct and mediating effects
}

\begin{abstract}
Big data has recently been recognized as one of the most important areas of future technology. It has attracted the attention of many industries, since it has the potential to provide companies with high business value. This paper examines the forms of business value that companies can create from big data analytics investments, the direct impacts it has on the financial performance of a firm, and the mediating effects of market performance and customer satisfaction. Drawing on the resource-based view theory, this study demonstrates that the business value achieved from investments in big data analytics leads to advantages in terms of the financial performance of a firm. The results offer evidence of the existence of a customer satisfaction mediation effect and of the absence of a market performance mediation effect. Theoretical and practical implications are discussed at the end of the paper.
\end{abstract}

\section{Keywords}

Big data analytics, business value, customer satisfaction, firm performance, resource-based view.

\section{Introduction}

Firms are involved in the rapid evolution of big data technologies and are increasingly interested in the potential of big data. Big data promises to create added value in a variety of operations (OECD, 2013) and has been identified as the next big thing in innovation (Gobble, 2013; Wamba, Gunasekaran, et al., 2017). However, a long list of Information Technology (IT) systems has been announced as being value creating, once implemented into organisations, without actually, satisfying the expectations: this is a recurrent bandwagon phenomenon in the IT domain, with recent examples coming from e-business (Coltman, Devinney, Latukefu, \& Midgley, 2000), green Information Systems (IS) (Dedrick, 2010) and blockchain (Avital, Beck, King, Rossi, \& Teigland, 2016). Hence, the complex and crucial question of "Whether, when, and how to innovate with information technology, confronts managers in virtually all of today's enterprises" (Swanson \& Ramiller, 2004, p. 553). Accordingly, when the innovation is highly debated and publicly promoted by policy makers and the mass media, as in the case of big data, deliberative behaviour can be swamped (Swanson \& Ramiller, 2004). Is big data the current "me too" phenomenon?

Based on the practical importance of big data in firms, provided also by policy makers and mass media, today firms try to leverage on big data and big data technologies in order to capture and profit from the enormous amount of data available from many sources, such as social media activities, radio frequency identification (RFID) tags, web information, mobile phone usage and consumer preferences expressed on the web (Davenport 2014). These business initiatives can imply profound changes in the way companies manage their customers and their business models. Accordingly, recent studies assert that "big data is more than a technological issue, and to be fully effective, big data needs to become part of the fabric of organisations" (Braganza, Brooks, Nepelski, Ali, \& Moro, 2017, p. 329).

Recent research suggests that big data is a driver of business success across a wide range of industries (McAfee et al. 2012). Organisations are investing considerable resources in big data initiatives in their search for value creation opportunities (Chen, Chiang, and Storey 2012), in order to drive their digital business strategies (Bharadwaj et al. 2013), to transform supply chains 
(Gunasekaran et al., 2017; G. Wang, Gunasekaran, Ngai, \& Papadopoulos, 2016), to allow them to make better-informed business decisions (Eastburn and Boland 2015), and finally to improve firm performance (Ji-fan Ren, Fosso Wamba, Akter, Dubey, \& Childe, 2016). Nonetheless, alerts are being launched to make managers aware of the fact that big data is not a panacea (Akter, Wamba, Gunasekaran, Dubey, \& Childe, 2016), "an uncritical analysis of poorly understood data sets does not generate knowledge" (Matthias et al., 2017, p. 41). Hence, research is needed to face the enormous challenge of knowing how big data can be used to support decision-making (Li, Song, \& Huang, 2016; Matthias et al., 2017), particularly considering the large expected investments in this domain. Prospectively, the worldwide revenues of big data and business analytics are expected to "grow from nearly $\$ 122$ billion in 2015 to more than $\$ 187$ billion in 2019, an increase of more than $50 \%$ over the five-year forecast period" (IDC 2016). However, all these investments could ruin companies (Braganza et al., 2017), if their management teams do not develop new perspective and innovative capabilities (Akter et al., 2016), and they are not able to let data talk through "interesting and insightful questions" (Matthias et al., 2017, p. 49). The same risk could affect those companies that manage inconsistent and unreliable data (Lukoianova \& Rubin, 2014).

In fact, companies have been overrun by a data-driven revolution in management (Tambe 2014). Several studies have focused on particular IT artefacts to manage data-related problems of the business practices and strategies of firms (George, Haas, and Pentland 2014; Lynch 2008; MayerSchönberger and Cukier 2013; Orlikowski and Scott 2015; Watson 2014). Among these, scant attention has been paid to big data analytics solutions, which have been defined as "a holistic approach to managing, processing and analysing the $5 \mathrm{~V}$ data-related dimensions (i.e. volume, variety, velocity, veracity and value) to create actionable insights in order to deliver sustained value, measure performance and establish competitive advantages" (Wamba, Akter, Edwards, Chopin, \& Gnanzou, 2015, p. 6). This holistic approach highlights the entanglement of three complementary dimensions in big data analytics: management, technology and human (Akter et al., 2016). On one hand, several research studies have covered the adoption and use of big data analytics solutions (Kwon, Lee, \& Shin, 2014; Malladi, 2013; Xu, Frankwick, \& Ramirez, 2016). On the other hand, practitioners and academics have highlighted the need to extend research beyond the post-adoption stages in order to understand how, why and when big data analytics can be a valuable resource for companies to gain competitive advantages (Abbasi, Sarker, \& Chiang, 2016; Agarwal \& Dhar, 2014; Côrte-Real, Oliveira, \& Ruivo, 2017; Erevelles, Fukawa, \& Swayne, 2016; LaValle, Lesser, Shockley, Hopkins, \& Kruschwitz, 2011; Xu et al., 2016). In fact, these analytics solutions could be the critical elements that are needed to transform overwhelming data into business value, and ultimately into business performance (Wilkins, 2013).

"Big data analytics is now considered as a game changer that can enable improved business efficiency and effectiveness because of its high operational and strategic potential" (Wamba, Gunasekaran, et al., 2017). A recent study (Ji-fan Ren et al., 2016) has looked at the relationship between the business value of big data analytics solutions and firm performance. On the one hand, the business value of these solutions has transactional, strategic and transformational aspects (Gregor et al. 2006). Nonetheless, it is expected that one central business value of big data analytics solutions is informational, and we have included this in our study. We refer to informational value as the ability to provide faster and easier access to data in more useable formats (Gregor et al. 2006). Informational value is largely recognised as being central to the evaluation of IT investments, and complementary to transactional, strategic and transformational values (Gregor et al. 2006; Ji-fan Ren et al. 2016; Love et al. 2005; Vorhies and Morgan 2005; Wu and Wang 2005). Without this informational dimension of business value, it may be possible to miss a key indicator of the capability to master data rather than be overwhelmed by it.

On the other hand, firm performance includes both financial and market performance. Financial performance refers to revenue growth and profitability, while market performance is more about 
improving a firm's position against its competitors (Mithas, Ramasubbu, and Sambamurthy 2011; Tippins and Sohi 2003). The results of this study suggest that the business value of big data analytics solutions has a direct impact on the performance of a firm, with no mediating or moderating effect (Ji-fan Ren et al. 2016). As far as firm performance as a dependent variable is concerned, we question whether market performance could to some extent be a mediator of the relationship between the business value of big data analytics solutions and financial performance. Market performance, that is, a firm's ability to anticipate and advance against competitors, could lead to better financial performance for several reasons. The expansion and the penetration of new markets (Homburg, Grozdanovic, and Klarmann 2007), and better products and services can increase the financial performance of companies (Szymanski and Henard 2001). Therefore, in this study we have considered market performance and financial performance as different constructs.

Finally, many authors have discussed the positive relationship between customer satisfaction and financial performance, in both service and manufacturing industries (e.g., Chi and Gursoy 2009). An increase in customer satisfaction could, for example, improve customer loyalty, which in turn generates higher cash flows. Customer satisfaction could be an important mediator between the business value of big data analytics solutions and the financial performance of a firm (Chumpitaz and Paparoidamis 2004). We aim to clarify whether customer satisfaction is capable of mediating the relationship between the business value of big data analytics solutions and the financial performance of a firm.

On the basis of these considerations, we propose an original model that is able to explain the performance of a firm in relation to the business value of big data analytics solutions. Our original contributions are centred on the inclusion of (1) the informational value as a complementary business value of big data analytics solutions in parallel with transactional, strategic and transformational values; (2) customer satisfaction and market performance as mediating variables between the business value of big data analytics solutions and the financial performance of a firm.

Overall, the aim of this study has been to address two research questions: 1) to what extent does the business value of big data analytics solutions increase the financial performance of a firm?; and 2) to what extent do customer satisfaction and market performance mediate the effect of the business value of big data analytics solutions on the financial performance of a firm?

The rest of the paper is structured as follows. First, we present the theoretical background from a resource-based point of view, and formulate our hypotheses. We then detail the methodology that we followed and present our results. We continue with a discussion of the findings, our conclusions and guidelines for future studies.

\section{Theoretical foundations and research hypotheses}

Interest in assessing business value, firm performance and big data analytics solutions is increasing (Akter et al., 2016; Kiron, Prentice, \& Ferguson, 2014; McAfee et al., 2012). Levering on previous literature that looked at the business values that are derived from IT solutions (Gregor et al., 2006), it has emerged that four different values have been applied to big data analytics solutions: transactional, strategic, transformational and informational. Transactional value refers to the ability of big data analytics solutions to provide operational benefits, such as a reduction in operating costs, enhancement of employee productivity or savings in supply chain management. Strategic value refers to the enhancement of a company's offer, for example, in terms of customer service or product innovations. Transformational value measures the capability of an organisation to change in order to take advantage of business opportunities or to transform its business model. Informational value, as already mentioned, refers to an organisation's ability to improve the flow of information, which in turn enables faster and easier access to data, and provides data in more useable formats. 
A complementary study has advanced a categorization of the different applications of big data, in relation to the scale and the time horizon (Matthias et al., 2017). The scale dimension refers to the narrowness of the big data application. Macro applications have the aim of covering entire business domains and several operations, such a whole supply chain (G. Wang et al., 2016). Micro applications have the aim of covering single operations within a specific business process, such as customer recommendations. The time horizon can refer to the past, present or future orientation of big data analysis, and is close to another classification of the nature of big data analytics, which defines it in descriptive, predictive or prescriptive terms (G. Wang et al., 2016). A past orientation could be applied to auditing and management control, and it could have a descriptive nature. A present orientation could be levered based on real-time reactions, and it could have a prescriptive nature. A future orientation could be beneficial when it is forward looking at new strategic initiatives (Gunasekaran et al., 2017), and it could have a predictive nature. The combination of micro and macro scales with past, present and future time horizons generates six categories (Matthias et al., 2017).

This categorization explains why big data analytics can provide business value in several stages of the value chain. Hence, big data analytics seems to stimulate operational and strategic improvements (Y. Wang, Kung, \& Byrd, 2016), automation (T. Davenport, 2014; Wamba et al., 2015), organizational agility (Côrte-Real et al., 2017; Y. Wang et al., 2016), knowledge management (Côrte-Real et al., 2017), other managerial activities (T. Davenport, 2014; Y. Wang et al., 2016), the IT infrastructure (Y. Wang et al., 2016), transparency (Wamba et al., 2015), experimentation and innovation (Tan, Zhan, Ji, Ye, \& Chang, 2015; Wamba et al., 2015), and customer segmentations (Wamba et al., 2015). In fact, several paths that leverage on big data analytics can lead to competitive advantages (Côrte-Real et al., 2017). However, firms need to implement specific processes in order to ensure that strategic repeatable benefits are obtained from big data investments. These processes enable firms to identify the resources that are required to ensure success, to overcome obstacles and develop specific capabilities (Braganza et al., 2017; Y. Wang et al., 2016).

The first evidence that has emerged from literature attests the opportunities of greatly improving performance (Akter et al., 2016; Wamba, Gunasekaran, et al., 2017; Wamba et al., 2015) and of creating a sustainable competitive advantage through the application of big data analytics (Matthias et al., 2017). For example, Wal-Mart's search engine for semantic analysis, Polaris, relies on text analysis and machine learning to produce relevant search results. Polaris may be a rare, inimitable and non-substitutable resource as it is a platform that was designed in-house. Adding this semantic search has increased the number of Wal-Mart online shoppers who complete a purchase by $10 \%$ to $15 \%$, thus creating a sustainable competitive advantage (Jayanand, Kumar, Srinivasa, \& Siddesh, 2014).

\section{The effect of the business value of big data analytics solutions on financial performance}

The extent to which big data analytics solutions can contribute to the creation of a competitive advance can be assessed by considering the resource-based view (RBV) (Wamba, Gunasekaran, et al., 2017). A firm is said to gain a competitive advantage from big data analytics solutions when it enjoys greater success than its competitors (Davenport 2006; Peteraf and Barney 2003). Thus, it is important to conceptualise the differences between business value and firm performance (Ji-fan Ren et al. 2016). In fact, RBV identifies business value as its central construct, between rare, inimitable and non-substitutable resources and firm performance (Kozlenkova, Samaha, and Palmatier 2014; Melville, Kraemer, and Gurbaxani 2004). In line with this conceptualisation of RBV, we propose that first a higher business value, and then a higher firm performance are empirical indicators of the competitive advantage that arises from big data analytics solutions. 
In first literature published on big data, it was characterised by three Vs: "high-Volume, highVelocity and/or high-Variety information assets that require cost-effective, innovative forms of information processing that enable enhanced insight, decision making and process automation" (Gartner 2012). A fourth and a fifth dimension were introduced later on: veracity (Lukoianova \& Rubin, 2014) and value (Wamba et al., 2015). Veracity refers to "the level of reliability associated with certain types of data" and it includes "truthfulness, accuracy or precision, correctness" (Schroeck, Shockley, Smart, Romero-Morales, \& Tufano, 2012).

Hence, the rare, inimitable and non-substitutable resources in the RBV perspective (Kaufman 2015) are the information assets, that are characterized by a high-volume, high-velocity, and/or highvariety, even though they are also characterised by low-veracity, and combined with cost-effective and innovative forms of information processing. The business value extracted from the resources is the fifth V component of big data. Accordingly, the most critical problem of big data is discovering and extracting value from a wide variety of rapidly generated, and not fully reliable databases on an enormous scale (Chen, Mao, and Liu 2014). Conversely, the financial performance of a firm is the ultimate dependent variable that measures the competitive advantage of a company (Kaufman 2015). A 15 to $20 \%$ increase in ROI for retailers who have put in place big data analytics has been found in literature (Wamba, Gunasekaran, et al., 2017). This result forms the basis of our first hypothesis:

H1: The business value of big data analytics solutions has a positive effect on the financial performance of a firm.

\section{The mediating effect of market performance}

Market performance refers to a company's ability to enter new markets more rapidly than its competitors, introduce new products and services more frequently, have a higher success rate with its new products and services, and have a higher market share. These can lead to a firm having a superior financial performance for several reasons. For example, the penetration of a new market can generate new revenues and higher product margins, thus impacting positively on the financial performance of a firm (Homburg et al. 2007). Similarly, a new product can stimulate an increase in purchases, which in turn generates positive recommendations among customers, in this way enhancing the financial performance of the selling company (Szymanski and Henard 2001). Given the importance that market performance has on financial performance, there is a need to clarify whether market performance is capable of mediating the relationship between the business value of big data analytics solutions and the financial performance of a firm, as it has been discovered in other contexts (Chumpitaz and Paparoidamis 2004). Scholars have advanced that big data should be incorporated in strategic marketing and new product development in order to be fully effective (Tan et al., 2015; Wamba et al., 2015; Xu et al., 2016) and to improve the market share (Wamba, Ngai, Riggins, \& Akter, 2017). Big data analytics would facilitate the definition of a market strategy through a data lens (Brands, 2014), and the segmentation of customers and population (Wamba et al., 2015). Applications of big data analytics could stimulate organizational agility and allow firms recognise market opportunities and threads, seize possible market chances and adjust the firm's products and services to the technological environment (Côrte-Real et al., 2017; T. Davenport, 2014). Finally, one new kind of commercial offer that levers on informatisation processes is the potentially disruptive creation of new revenue streams by selling information that is complementary to the traditional product and service offers (Opresnik \& Taisch, 2015). This forms the basis of our second hypothesis:

H2: Market performance has a mediating effect on the relationship between the business value of big data analytics solutions and the financial performance of a firm. 


\section{The mediating effect of customer satisfaction}

Customer satisfaction is a function of how goods and services meet or surpass the expectations of customers. Customers compare the perceived performance of a product with a performance standard. They are satisfied when the perceived performance is greater than the standard, and dissatisfied when performance falls short of the standard. Customer satisfaction is considered to affect customer retention and, therefore, profitability (Anderson and Sullivan 1993). According to previous research (Jones, 1996), complete customer satisfaction is the key to securing customer loyalty and generating superior long-term financial performance (Storbacka, Strandvik, and Grönroos 1994).

Customer satisfaction is an important driver of financial performance in both service and manufacturing realities. Many authors have discussed the positive relationship between the two variables (e.g., Chi and Gursoy 2009). An increase in customer satisfaction can be related to an improvement in the understanding of what customers want, via a big data analytics solution, so that the loyalty of customers is increased and, in return, future cash flows are enhanced. Firms could attempt to use big data to increase customer satisfaction (Wamba, Ngai, et al., 2017). The emerging literature has identified a positive relationship between the deployment of big data analytics of customer data and firm performance (Wamba, Gunasekaran, et al., 2017), and a decrease in customer acquisition costs of about 47\% (Liu, 2014), a closer customer relationship (Cheng, Zhang, \& Qin, 2016), more customization (Wamba et al., 2015) and a better overall customer experience (Tan et al., 2015; Tweney, 2013) have been observed.

In conclusion, customer satisfaction could be an important mediator between the business value of big data analytics solutions and the financial performance of a firm. This forms the basis of our third hypothesis:

H3: Customer satisfaction has a mediating effect on the relationship between the business value of big data analytics solutions and the financial performance of a firm.

The aim of this work has been to test the research model shown in Figure 1 by drawing on RBV. We argue that the business value derived from the use of big data analytics solutions has an impact on the financial performance of a firm, through the contribution of two mediating variables: customer satisfaction and market performance.

The mathematical representation of Figure 1, which refers to the effects that are estimated in the present paper, the indirect effect of $X$ on $Y$ through $M_{1}=a_{1} b_{1}, M_{2}=a_{2} b_{2}$, and the direct effect of $X$ on $\mathrm{Y}=\mathrm{c}^{\prime}$, is shown hereafter:

$$
\begin{gathered}
M_{1}=a_{0}+a_{1} X+e_{M 1} \\
M_{2}=b_{0}+a_{2} X+e_{M 2} \\
Y=c^{\prime}{ }^{0}+c^{\prime} X+b_{1} M_{1}+b_{2} M_{2}+e_{Y^{*}} \\
Y=c_{0}+c X+e_{Y}
\end{gathered}
$$

--- Figure 1 around here ---

\section{Research method}

\section{Scale development and sampling}

In order to test the above formulated hypotheses, we delivered a questionnaire to a sample of French companies. Before sending the final questionnaire, several preliminary steps were necessary. 
First, we conducted a pilot study on a sample of 30 companies to test the comprehensibility of the questions that were to be included in the questionnaire, to ensure the reliability and validity of the measures, and to estimate the final response rate. The final items used in the questionnaire and their sources are listed in Table 1.

--- Table 1 around here ---

As our study has been conducted at a firm level, we referred to previous studies (Ji-fan Ren et al. 2016) and targeted the Chief Information Officer (CIO). A random sampling method was implemented to select 1,962 medium and large French companies to interview from a total of 19,875 registered in the Bureau Van Dijk database. Each company was contacted and informed about the aim of the research study and asked to supply the contact details of their CIO or an equivalent figure. Subsequently, the CIO was contacted by phone to obtain his/her participation consent. The final questionnaire, in which the comments of the pilot test were taken into account, was delivered to a sample of companies in order to evaluate the benefits and risks that they face when adopting and implementing big data analytics solutions. Overall, 200 questionnaires were gathered. The final sample was composed of 86.5\%reAKRD013LL\&KD0 3MLSAD0 3WLKA7KqLALD0m3LS:R 


\section{Data analysis}

Variance-based structural equation modelling was used in this study to test the links hypothesised in our conceptual framework. The model measures are reflective, which means that the latent variables reflect the manifest variables (LVs $\rightarrow$ MVs).

We used a two-step procedure to apply the structural equation modelling (Anderson and Gerbing 1988). The first step involves testing the measurement model and the second the structural model. The measurement model basically verifies the reliability, uni-dimensionality, convergent validity and discriminant validity of the construct. The second step tests the structural model and verifies the structural relationships represented by our hypotheses.

\section{Measurement model}

We used ADANCO to assess the measurement model. ADANCO is a software application for variance-based structural equation modelling that implements several limited-information estimators. In our case, we applied a path weighting scheme for the inside approximation. Nonparametric bootstrapping (Chin 2001) was then applied with 5,000 replications to obtain the standard errors of the estimates (Hair, Ringle, and Sarstedt 2013).

Table 4 shows the psychometric properties of the measures investigated in this study. The loadings of the measures on their respective constructs ranged from 0.672 to 0.880 . We consider these loadings satisfactory (Hair, Black, Babin, Anderson, and Tatham 1998). The t-statistic of each factor loading was compounded to verify convergent validity. All the factor loadings are found to be statistically significant, and all the t-values were higher than the cut-off point of 1.980 . The overall constructs are meritorious, given that the Kaiser-Meyer-Olkin measure of the sampling adequacy is equal to 0.843 and that Bartlett's test of sphericity gives a statistically significant chisquare value of $1,156(\mathrm{p}$-value $=0.001)$. The recommended reliability levels and the average variance extracted (AVE) were also observed. Cronbach's alpha values ranged from 0.670 to 0.839 , and the AVE values ranged from 0.516 to 0.676 . These values are higher than the acceptability threshold values (Bagozzi and Yi 1988; Churchill Jr 1979). These results reveal the presence of convergent validity in the measurement model. Uni-dimensionality is also confirmed by the AVE values $(>0.50)$.

The variance explained by each principal factor was also tested to identify any potential common method bias (Podsakoff and Organ 1986). Harman's one-factor test showed that the first factor only accounts for $23.542 \%$ of the total variance, which indicates that the common method bias would not be a serious problem. Furthermore, the correlation matrix (Table 5) shows that the highest inter-construct correlation is 0.602 , while the common method bias is usually evidenced by extremely high correlations ( $r>0.90$ ) (Bagozzi, Yi, and Phillips 1991). Therefore, it is possible to state that the common method bias in this research has not been a serious issue.

\section{--- Table 4 around here --- \\ --- Table 5 around here ---}

Table 5 shows the discriminant validity of our variables measured with Likert scales. The square root of AVE was compared for each construct with correlations between each construct and the remaining constructs (Fornell and Larcker 1981). Each construct shared more variance with its own measurement items than with the constructs of the different measurement items. Therefore, discriminant validity was supported. 
Table 7 results indicate that the direct effect of business value of big data analytics solutions on the financial performance of firms is significant ( $\mathrm{p}$-value $=0.012$ ) and equal to 0.345 . This result fully supports Hypothesis 1 , in which it was stated that the business value of big data analytics solutions has a positive impact on the financial performance of a firm.

Table 7 also highlights that market performance has no mediating effect on the relationship between the business value of big data analytics solutions and the financial performance of a firm. The bootstrapping range between the lower (LLCI=-0.165) and the upper confidence level (ULCI $=0.275$ ) of the market performance variable, pertaining to the indirect effect of the business value on financial performance, includes 0 . This provides a first evidence of the no mediating effect of the market performance. Furthermore, when considering Table 6, it appears that the business value of big data analytics solutions has a positive effect on market performance, with a coefficient of 0.971 , a p-value of less than 0.001 and an $\mathrm{R}$ of $71.90 \%$. However, when the outcome variable is the financial performance, and the three variables market performance, customer satisfaction and business value are the independent variables, market performance has a low significant $p$-value (pvalue higher that the 0.05 threshold of significance). This provides a second evidence of the no mediating effect of the market performance. Thus, considering these two results, it is possible to conclude that Hypothesis 2, in which it was stated that market performance has a mediating effect on the relationship between the business value of big data analytics solutions and firm financial performance, has not been verified.

Moreover, Table 7 shows that customer satisfaction has a significant mediating effect on the relationship between the business value of big data analytics solutions and the financial 
performance of a firm. The bootstrapping range between the lower $(\mathrm{LLCI}=0.209)$ and the upper confidence level (ULCI $=0.714$ ) of the customer satisfaction variable, pertaining to the indirect effect of the business value on financial performance, does not include 0 . This provides a first evidence of the mediating effect of the customer satisfaction. Furthermore, when considering Table 6 , it emerges that the business value of big data analytics solutions has a positive effect on customer satisfaction, with a coefficient of 0.888 , a lower $\mathrm{p}$-value than 0.001 and an $\mathrm{R}$ of $62.38 \%$. At the same time, when the outcome variable is financial performance and the three independent variables are customer satisfaction, market performance and business value, customer satisfaction has a high significant $p$-value (lower p-value than 0.001 ) and a coefficient of 0.486 for an $\mathrm{R}$ of $78.64 \%$. This provides a second evidence of the mediating effect of the customer satisfaction. Considering these two results, it is possible to conclude that $\mathrm{H3}$, in which it was stated that customer satisfaction has a mediating effect on the relationship between the business value of big data analytics solutions and firm financial performance, has been confirmed.

In addition, the total effect of the complete model (0.470) is higher than the single direct effect of business value on financial performance (0.345), thus showing the importance of the indirect effect of customer satisfaction on financial performance. Hence, the impact of the business value of a big data analytics solution is explained better considering the mediation of customer satisfaction than by market performance.

The completely standardized indirect effect of business value on financial performance confirms the previous results, simply with slightly lowering the effects.

\section{Discussion}

\section{Summary of the findings}

The present study has provided a useful perspective to explore the translation of business value, in terms of transactional, strategic, transformational and informational value, of the financial performance of a firm in a big data environment. The primary objective of this study was to examine the effects of the business value of big data analytics solutions on the financial performance of a firm, both directly and indirectly, through customer satisfaction and market performance. The results show that the business value of big data analytics solutions is able to explain $62.4 \%$ of the variance of customer satisfaction, $71.9 \%$ of the variance of market performance, and $78.6 \%$ of the variance of financial performance. However, only business value and customer satisfaction have an effect on financial performance, that is, of 0.345 and 0.432 , respectively, for the direct effect of business value and the indirect effect of customer satisfaction, with a total effect of 0.470 . It is evident that customer satisfaction has more influence on financial performance than market performance or the direct impact of business value. On the other hand, market performance does not appear to have a mediating effect on financial performance.

\section{Implications for research}

Firms spend millions of dollars on analytics solutions to enhance their business value and ultimately the financial performance of the firms (H. Chen et al., 2012; Ji-fan Ren et al., 2016). However, the impact of analytics solutions on the success of a business is rife with obstacles (McAfee et al., 2012). Therefore, understanding how big data analytics solutions can improve the financial performance of a firm is a critical challenge for big data research. Our findings clearly enrich the debate (Akter et al., 2016; Ji-fan Ren et al., 2016; Wamba, Gunasekaran, et al., 2017; Wamba et al., 2015) on the business value of big data analytics solutions and how to leverage them to enhance the financial performance of a firm. 
Our conceptual framework is grounded on the RBV theory of a firm and extends this theory to the field of big data analytics solutions. The RBV theory of a firm helps to overcome the obstacles to transforming big data investment into competitive advantage and to finding solutions. RBV explains why some big data analytics solutions fail to generate business value when they do not have the characteristics anticipated by this theory: rarity, inimitability, non-substitutability (Kozlenkova et al., 2014; Melville et al., 2004). Among the several paths through which big data analytics can lead to competitive advantage (Côrte-Real et al., 2017), our study shows the effectiveness of big data analytics solutions in sustaining competitive advantage via a superior business value, greater customer satisfaction and better firm performance.

To the best of the authors' knowledge, this is the first study to show the importance, in the big data domain, of the mediating effects of customer satisfaction on financial performance (Chi \& Gursoy, 2009; Chumpitaz \& Paparoidamis, 2004) and the absence of a mediating effect, via market performance, in the big data domain. Our hypothesis on whether market performance could be a mediator to some extent has not been confirmed. This mean that the expansion and the penetration of new markets, as well as better products and services, do not play mediating roles of the business value of big data analytics solutions on the financial performance of a firm.

Although business value has been found to have a significant direct impact on financial performance, as previously demonstrated (Ji-fan Ren et al., 2016), customer satisfaction has been observed to partially mediate this direct relationship. Big data analytics solutions create business value that can be applied effectively to improve customer satisfaction and market performance, as attested outside the big data domain (Chumpitaz \& Paparoidamis, 2004; Szymanski \& Henard, 2001). Big data analytics solutions seem to improve the understanding of what customers want, and firms are able to better customize their offer in order to increase customers' satisfaction and loyalty (Cheng et al., 2016; Tan et al., 2015; Tweney, 2013; Wamba, Gunasekaran, et al., 2017) and to decrease customer acquisition costs (Wamba et al., 2015), which are key ingredients for enhanced cash flows and more in general for enhanced financial performance (Wamba, Gunasekaran, et al., 2017). Moreover, our study has developed and validated an enriched construct to measure the business value of IT solutions (Gregor et al., 2006) in which there are four different dimensions: transactional, strategic, transformational and informational value. Informational value is the least explored dimension in literature (Ji-fan Ren et al., 2016), even though it has theoretically been recognized as being central to the evaluation of IT investments.

This study has extended relevant theories in big data analytics solutions by framing, in an original combination, four dimensions of the business value of big data analytics solutions on one outcome construct, that is, financial performance and the mediation variable of customer satisfaction.

\section{Implications for practice}

The model we have proposed provides those managers who are more and more interested in big data (T. Davenport, 2014; IDC, 2016) with a tool that can be used to conduct an integrated analysis of the impact of big data analytics solutions on firm performance. Insofar as the changes may be profound, it is important to help managers understand the different value-generating opportunities of big data analytics solutions and their translation processes in terms of firm performance. Our results point out that big data maintains the promise of creating added value. Big data analytics solutions facilitate the entry of a firm onto new markets, the release of innovative products and the possibility of beating competitors. Big data analytics solutions help a company to satisfy its customers with better products and services than the competition. Finally, big data analytics 
solutions enhance the financial performance of a firm, as far as customer retention, sales growth and profitability are concerned.

Moreover, the findings highlight the role of the business value of big data analytics solutions and customer satisfaction as decision-making variables in predicting the financial performance of a firm. On the other hand, the positive contribution of big data to market performance does not result, in higher financial performances of a firm. In fact, the financial performance of a firm is the ultimate outcome variable. Nonetheless, some open challenges related to identifying and replicating the best big data analytics solution practices that could enhance financial performance still have to be overcome (Ji-fan Ren et al., 2016). Hence, directing managerial attention first towards business value and then towards customer satisfaction could be an effective way of channelling the overwhelming amount of data towards operational objectives, without immediately targeting financial performance.

The findings on the financial performance of a firm and the investigated mediation effects will facilitate the scalability of big data analytics solutions. These findings suggest that managers should consider customer satisfaction as an important strategic objective to ensure an improved financial performance of their firms. However, managers should be aware of the fact that some differences could emerge, depending on the particular IT artefacts in which they want to invest (George et al., 2014; Lynch, 2008; Mayer-Schönberger \& Cukier, 2013; Orlikowski \& Scott, 2015; Watson, 2014).

\section{Limitations and future research}

This study has some limitations that open up interesting opportunities for future research. First, this study has had a cross-sectional research design, in which all the measurement items were collected at the same point of time. A longitudinal study could extend this research by capturing the dynamics of the business value of big data analytics solutions on different firm performances. Second, this research has employed one data collection method. Objective data from multiple sources could be used to further verify the proposed research model. The decision to use companies from the Bureau Van Dijk database in fact opens up the possibility of combining objective data as soon as they become available.

\section{Conclusion}

Even though investments in big data analytics solutions are still very risky, the organizations that have invested successfully are able to profit from better customer satisfaction and higher market performance. Moreover, customer satisfaction and business value ultimately enhance the financial performance of a firm. Big data analytics solutions should be designed holistically to generate transactional, transformational, strategic and informational values. The findings of this study will help to enrich scientific knowledge at the crossroads of technology and management sciences. However, there are still many unanswered questions, some of which have explicitly been highlighted in this article, which will ensure that the big data field remains fruitful for further research.

\section{References}

Abbasi, A., Sarker, S., \& Chiang, R. H. (2016). Big Data Research in Information Systems: Toward an Inclusive Research Agenda. Journal of the Association for Information Systems, 17(2). Retrieved from

https://www.researchgate.net/profile/Ahmed_Abbasi4/publication/298717827_Big_data_research_i $\mathrm{n}$ _information_systems_Toward_an_inclusive_research_agenda/links/57052eb908ae13eb88b9409d .pdf 
Agarwal, R., \& Dhar, V. (2014). Big data, data science, and analytics: The opportunity and challenge for IS research. INFORMS. Retrieved from http://pubsonline.informs.org/doi/abs/10.1287/isre.2014.0546

Akter, S., Wamba, S. F., Gunasekaran, A., Dubey, R., \& Childe, S. J. (2016). How to improve firm performance using big data analytics capability and business strategy alignment? International Journal of Production Economics, 182, 113-131.

Anderson, E. W., \& Sullivan, M. W. (1993). The antecedents and consequences of customer satisfaction for firms. Marketing Science, 12(2), 125-143.

Anderson, J. C., \& Gerbing, D. W. (1988). Structural equation modeling in practice: A review and recommended two-step approach. Psychological Bulletin, 103(3), 411.

Avital, M., Beck, R., King, J., Rossi, M., \& Teigland, R. (2016). Jumping on the Blockchain Bandwagon: Lessons of the Past and Outlook to the Future. Retrieved from http://aisel.aisnet.org/icis2016/Panels/Presentations/6/

Bagozzi, R. P., \& Yi, Y. (1988). On the evaluation of structural equation models. Journal of the Academy of Marketing Science, 16(1), 74-94.

Bagozzi, R. P., Yi, Y., \& Phillips, L. W. (1991). Assessing construct validity in organizational research. Administrative Science Quarterly, 421-458.

Bharadwaj, A., El Sawy, O. A., Pavlou, P. A., \& Venkatraman, N. V. (2013). Digital business strategy: toward a next generation of insights. Retrieved from https://papers.ssrn.com/sol3/papers.cfm?abstract_id=2742300

Braganza, A., Brooks, L., Nepelski, D., Ali, M., \& Moro, R. (2017). Resource management in big data initiatives: Processes and dynamic capabilities. Journal of Business Research, 70, 328-337.

Brands, K. (2014). Big Data and Business Intelligence for Management Accountants. Strategic Finance.

Chen, H., Chiang, R. H., \& Storey, V. C. (2012). Business intelligence and analytics: From big data to big impact. MIS Quarterly, 36(4), 1165-1188.

Chen, M., Mao, S., \& Liu, Y. (2014). Big data: a survey. Mobile Networks and Applications, 19(2), 171-209.

Cheng, S., Zhang, Q., \& Qin, Q. (2016). Big data analytics with swarm intelligence. Industrial Management \& Data Systems, 116(4), 646-666.

Chi, C. G., \& Gursoy, D. (2009). Employee satisfaction, customer satisfaction, and financial performance: An empirical examination. International Journal of Hospitality Management, 28(2), $245-253$.

Chin, W. W. (2001). PLS-Graph user's guide. CT Bauer College of Business, University of Houston, USA, 15. Retrieved from http://www.spsspasw.ir/upload/images/ei8gx66re11 tenmq0sm.pdf

Chumpitaz, R., \& Paparoidamis, N. G. (2004). Service quality and marketing performance in business-to-business markets: exploring the mediating role of client satisfaction. Managing Service Quality: An International Journal, 14(2/3), 235-248. 
Churchill Jr, G. A. (1979). A paradigm for developing better measures of marketing constructs. Journal of Marketing Research, 64-73.

Coltman, T., Devinney, T. M., Latukefu, A., \& Midgley, D. F. (2000). E-business: revolution, evolution or hype? WORKING PAPER-AUSTRALIAN GRADUATE SCHOOL OF MANAGEMENT, (2). Retrieved from http://www.uazuay.edu.ec/bibliotecas/e-business/Ebusiness_Revolution_Evolution_or_Hype.pdf

Côrte-Real, N., Oliveira, T., \& Ruivo, P. (2017). Assessing business value of Big Data Analytics in European firms. Journal of Business Research, 70, 379-390.

Darlington, R. B., \& Hayes, A. F. (2016). Regression analysis and linear models: Concepts, applications, and implementation. Guilford Publications. Retrieved from https://books.google.it/books?hl=en\&lr=\&id=YDgoDAAAQBAJ\&oi=fnd\&pg=PP1\&dq=Regressio $\mathrm{n}+$ Analysis + and + Linear + Models,$+\&$ ots $=8 \mathrm{gEWzMkGxD \& sig}=$ hj9X4CDPL6MTHx2gtaCJ1gQcnT 8

Davenport, T. (2014). Big data at work: dispelling the myths, uncovering the opportunities. Harvard Business Review Press. Retrieved from https://books.google.it/books?hl=en\&lr=\&id=apjBAgAAQBAJ\&oi=fnd\&pg=PR5\&dq=davenport+ 2014\&ots=flIekv7xOt\&sig=5iKAjW6w4HONSFoVQAYaZ1jImbE

Davenport, T. H. (2006). Competing on analytics. Harvard Business Review, 84(1), 98.

Dedrick, J. L. (2010). Green IS: Concepts and issues for information systems research. CAIS, 27, 11 .

Diamantopoulos, A., \& Siguaw, J. A. (2006). Formative versus reflective indicators in organizational measure development: A comparison and empirical illustration. British Journal of Management, 17(4), 263-282.

Eastburn, R. W., \& Boland, R. J. (2015). Inside banks' information and control systems: Postdecision surprise and corporate disruption. Information and Organization, 25(3), 160-190.

Erevelles, S., Fukawa, N., \& Swayne, L. (2016). Big Data consumer analytics and the transformation of marketing. Journal of Business Research, 69(2), 897-904.

Fornell, C., \& Larcker, D. F. (1981). Evaluating structural equation models with unobservable variables and measurement error. Journal of Marketing Research, 39-50.

Gartner. (2012). Gartner IT Glossary. Retrieved from http://www.gartner.com/it-glossary/big-data/

George, G., Haas, M. R., \& Pentland, A. (2014). Big data and management. Academy of Management Journal, 57(2), 321-326.

Gobble, M. (2013). Big Data: The Next Big Thing in Innovation. Research and Technology Management, 56(1), 64-66.

Gregor, S., Martin, M., Fernandez, W., Stern, S., \& Vitale, M. (2006). The transformational dimension in the realization of business value from information technology. The Journal of Strategic Information Systems, 15(3), 249-270. 
Gunasekaran, A., Papadopoulos, T., Dubey, R., Wamba, S. F., Childe, S. J., Hazen, B., \& Akter, S. (2017). Big data and predictive analytics for supply chain and organizational performance. Journal of Business Research, 70, 308-317.

Hair, J. F., Black, W. C., Babin, B. J., Anderson, R. E., \& Tatham, R. L. (1998). Multivariate data analysis . Uppersaddle River. Multivariate Data Analysis (5th Ed) Upper Saddle River.

Hair, J. F., Ringle, C. M., \& Sarstedt, M. (2013). Editorial-partial least squares structural equation modeling: Rigorous applications, better results and higher acceptance. Retrieved from https://papers.ssrn.com/soL3/papers.cfm?abstract_id=2233795

Homburg, C., Grozdanovic, M., \& Klarmann, M. (2007). Responsiveness to customers and competitors: the role of affective and cognitive organizational systems. Journal of Marketing, 71(3), $18-38$.

IDC. (2016). Worldwide Big Data and Business Analytics Revenues Forecast to Reach \$187 Billion in 2019, According to IDC. Retrieved https://www.idc.com/getdoc.jsp?containerId=prUS41306516

Jayanand, M., Kumar, M. A., Srinivasa, K. G., \& Siddesh, G. M. (2014). Big data computing strategies. Handbook of Research on Securing Cloud-Based Databases with Biometric Applications, 72.

Ji-fan Ren, S., Fosso Wamba, S., Akter, S., Dubey, R., \& Childe, S. J. (2016). Modelling quality dynamics, business value and firm performance in a big data analytics environment. International Journal of Production Research, 1-16.

Jones, T. O. (1996). Why satisfied customers defect. Journal of Management in Engineering, 12(6), $11-11$.

Kaufman, B. E. (2015). The RBV theory foundation of strategic HRM: critical flaws, problems for research and practice, and an alternative economics paradigm. Human Resource Management Journal, 25(4), 516-540.

Kiron, D., Prentice, P. K., \& Ferguson, R. B. (2014). The analytics mandate. MIT Sloan Management Review, 55(4), 1.

Kozlenkova, I. V., Samaha, S. A., \& Palmatier, R. W. (2014). Resource-based theory in marketing. Journal of the Academy of Marketing Science, 42(1), 1-21.

Kwon, O., Lee, N., \& Shin, B. (2014). Data quality management, data usage experience and acquisition intention of big data analytics. International Journal of Information Management, 34(3), $387-394$.

LaValle, S., Lesser, E., Shockley, R., Hopkins, M. S., \& Kruschwitz, N. (2011). Big data, analytics and the path from insights to value. MIT Sloan Management Review, 52(2), 21.

Li, X., Song, J., \& Huang, B. (2016). A scientific workflow management system architecture and its scheduling based on cloud service platform for manufacturing big data analytics. The International Journal of Advanced Manufacturing Technology, 84(1-4), 119-131.

Liu, Y. (2014). Big data and predictive business analytics. The Journal of Business Forecasting, $33(4), 40$. 
Love, P. E., Irani, Z., Standing, C., Lin, C., \& Burn, J. M. (2005). The enigma of evaluation: benefits, costs and risks of IT in Australian small-medium-sized enterprises. Information \& Management, 42(7), 947-964.

Lukoianova, T., \& Rubin, V. L. (2014). Veracity roadmap: Is big data objective, truthful and credible? Retrieved from http://ir.lib.uwo.ca/fimspub/62/

Lynch, C. (2008). Big data: How do your data grow? Nature, 455(7209), 28-29.

Malladi, S. (2013). Adoption of Business Intelligence \& Analytics in Organizations-An Empirical Study of Antecedents. from http://aisel.aisnet.org/amcis2013/BusinessIntelligence/GeneralPresentations/3/

Matthias, O., Matthias, O., Fouweather, I., Fouweather, I., Gregory, I., Gregory, I., ... Vernon, A. (2017). Making sense of Big Data-can it transform operations management? International Journal of Operations \& Production Management, 37(1), 37-55.

Mayer-Schönberger, V., \& Cukier, K. (2013). Big data: A revolution that will transform how we live, work, and think. Houghton Mifflin Harcourt. Retrieved from https://books.google.it/books?hl=en\&lr=\&id=uy4lh-WEhhIC\&oi=fnd\&pg=PP1\&dq=MayerSch\%C3\%B6nberger, + V., + Cukier, + K. $+(2013),+$ Big + Data: + A + Revolution+That + Will + Transform + How + We+Live, + Work,, and+Think,,+ Houghton+Mifflin+Harcourt, + New + York,,+ USA.\&ots=Jsk 8gkGVIS\&sig=MKY5Nt3ZXDsuekUiQzfv3ybR6yk

McAfee, A., Brynjolfsson, E., Davenport, T. H., Patil, D. J., \& Barton, D. (2012). Big data. The Management Revolution. Harvard Bus Rev, 90(10), 61-67.

Melville, N., Kraemer, K., \& Gurbaxani, V. (2004). Review: Information technology and organizational performance: An integrative model of IT business value. MIS Quarterly, 28(2), 283322.

Mithas, S., Ramasubbu, N., \& Sambamurthy, V. (2011). How information management capability influences firm performance. MIS Quarterly, 237-256.

Montoya, A. K., \& Hayes, A. F. (2017). Two-condition within-participant statistical mediation analysis: A path-analytic framework. Psychological Methods, 22(1), 6.

OECD. (2013). Exploring data-driven innovation as a new source of growth: mapping the policy issues raised by “ 'big data'.” OECD Digital Economy Papers, No. 222, OECD Publishing.

Opresnik, D., \& Taisch, M. (2015). The value of Big Data in servitization. International Journal of Production Economics, 165, 174-184.

Orlikowski, W., \& Scott, S. V. (2015). The Algorithm and the crowd: Considering the materiality of service innovation. Retrieved from https://dspace.mit.edu/handle/1721.1/96870

Peteraf, M. A., \& Barney, J. B. (2003). Unraveling the resource-based tangle. Managerial and Decision Economics, 24(4), 309-323.

Podsakoff, P. M., \& Organ, D. W. (1986). Self-reports in organizational research: Problems and prospects. Journal of Management, 12(4), 531-544. 
Schroeck, M., Shockley, R., Smart, J., Romero-Morales, D., \& Tufano, P. (2012). Analytics: the real-world use of big data: How innovative enterprises extract value from uncertain data, Executive Report. IBM Institute for Business Value and Said Business School at the University of Oxford.

Storbacka, K., Strandvik, T., \& Grönroos, C. (1994). Managing customer relationships for profit: the dynamics of relationship quality. International Journal of Service Industry Management, 5(5), 21-38.

Swanson, E. B., \& Ramiller, N. C. (2004). Innovating mindfully with information technology. MIS Quarterly, 553-583.

Szymanski, D. M., \& Henard, D. H. (2001). Customer satisfaction: A meta-analysis of the empirical evidence. Journal of the Academy of Marketing Science, 29(1), 16-35.

Tambe, P. (2014). Big data investment, skills, and firm value. Management Science, 60(6), $1452-$ 1469.

Tan, K. H., Zhan, Y., Ji, G., Ye, F., \& Chang, C. (2015). Harvesting big data to enhance supply chain innovation capabilities: An analytic infrastructure based on deduction graph. International Journal of Production Economics, 165, 223-233.

Tippins, M. J., \& Sohi, R. S. (2003). IT competency and firm performance: is organizational learning a missing link? Strategic Management Journal, 24(8), 745-761.

Tweney, D. (2013). Walmart scoops up Inkiru to bolster its "big data"capabilities online. Retrieved.

Vorhies, D. W., \& Morgan, N. A. (2005). Benchmarking marketing capabilities for sustainable competitive advantage. Journal of Marketing, 69(1), 80-94.

Wamba, S. F., Akter, S., Edwards, A., Chopin, G., \& Gnanzou, D. (2015). How "big data"can make big impact: Findings from a systematic review and a longitudinal case study. International Journal of Production Economics, 165, 234-246.

Wamba, S. F., Gunasekaran, A., Akter, S., Ren, S. J., Dubey, R., \& Childe, S. J. (2017). Big data analytics and firm performance: Effects of dynamic capabilities. Journal of Business Research, 70, 356-365.

Wamba, S. F., Ngai, E. W., Riggins, F., \& Akter, S. (2017). Guest editorial. International Journal of Operations \& Production Management, pp. 2-9.

Wang, G., Gunasekaran, A., Ngai, E. W., \& Papadopoulos, T. (2016). Big data analytics in logistics and supply chain management: Certain investigations for research and applications. International Journal of Production Economics, 176, 98-110.

Wang, Y., Kung, L., \& Byrd, T. A. (2016). Big data analytics: Understanding its capabilities and potential benefits for healthcare organizations. Technological Forecasting and Social Change. Retrieved from http://www.sciencedirect.com/science/article/pii/S0040162516000500

Watson, H. J. (2014). Tutorial: Big data analytics: Concepts, technologies, and applications. Communications of the Association for Information Systems, 34(1), 1247-1268.

Wilkins, J. (2013). Big data and its impact on manufacturing. Retrieved from www.dpaonthenet.net/ article/65238/Big-data-and-its-impact-on-manufacturing.aspx 
Wu, J.-H., \& Wang, S.-C. (2005). What drives mobile commerce?: An empirical evaluation of the revised technology acceptance model. Information \& Management, 42(5), 719-729.

Xu, Z., Frankwick, G. L., \& Ramirez, E. (2016). Effects of big data analytics and traditional marketing analytics on new product success: A knowledge fusion perspective. Journal of Business Research, 69(5), 1562-1566. 
Figure 1 Research model

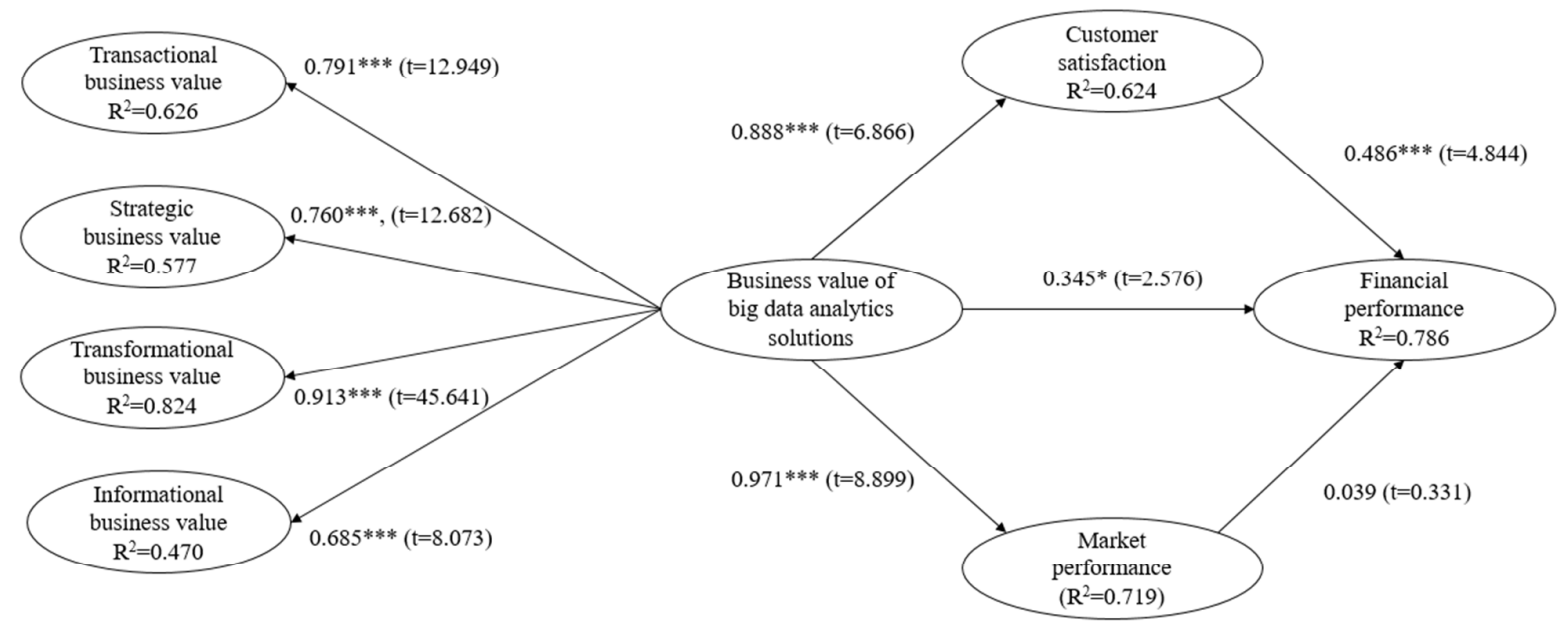

${ }^{* *} p$-value $<0.1 \% ; * * p<1 \% ; * p<5 \% ;{ }^{\dagger} p<10 \%$.

Figure 2 Full structural model 
Tables

Table 1 Constructs, items and references

\begin{tabular}{|c|c|c|}
\hline Construct & ID* & Sub-dimension \\
\hline \multirow{4}{*}{$\begin{array}{l}\text { Transactional value (Gregor } \\
\text { et al. 2006; Ji-fan Ren et al. } \\
\text { 2016) }\end{array}$} & TAB1 & Savings in supply chain management \\
\hline & TAB2 & Reducing operating costs \\
\hline & TAB3 & Reducing communication costs \\
\hline & TAB4 & Enhancing employee productivity \\
\hline \multirow{3}{*}{$\begin{array}{l}\text { Strategic value (Gregor et al. } \\
\text { 2006; Ji-fan Ren et al. 2016) }\end{array}$} & SB1 & Creating competitive advantage \\
\hline & SB2 & Enabling quicker response to change \\
\hline & SB3 & Improving customer relations \\
\hline \multirow{4}{*}{$\begin{array}{l}\text { Transformational value } \\
\text { (Gregor et al. 2006; Ji-fan } \\
\text { Ren et al. 2016) }\end{array}$} & TFB1 & An improved skill level for employees \\
\hline & TFB2 & Developing new business opportunities \\
\hline & TFB3 & Expanding capabilities \\
\hline & TFB4 & Improving organization \\
\hline \multirow{3}{*}{$\begin{array}{l}\text { Informational value (Gregor } \\
\text { et al. 2006) }\end{array}$} & IB1 & Enabling faster access to data \\
\hline & IB2 & Improving management data \\
\hline & IB3 & Improving data accuracy \\
\hline \multirow{3}{*}{$\begin{array}{l}\text { Financial performance (Ji- } \\
\text { fan Ren et al. 2016; Mithas } \\
\text { et al. 2011) }\end{array}$} & FP1 & Customer retention \\
\hline & FP2 & Sales growth \\
\hline & FP3 & Profitability \\
\hline \multirow{4}{*}{$\begin{array}{l}\text { Market performance (Ji-fan } \\
\text { Ren et al. 2016) }\end{array}$} & MP1 & Entering new markets more quickly than our competitors \\
\hline & MP2 & Introducing new products or services to the market faster than our competitors \\
\hline & MP3 & Higher success rate of new products or services than our competitors \\
\hline & MP4 & Market share has exceeded that of our competitors \\
\hline \multirow{4}{*}{$\begin{array}{l}\text { Customer satisfaction } \\
\text { (Mithas et al. 2011; Vorhies } \\
\text { and Morgan 2005) }\end{array}$} & CS1 & Increasing customer satisfaction \\
\hline & CS2 & Delivering more value to our customers \\
\hline & CS3 & Improving the delivery of what our customers want \\
\hline & CS4 & Retaining valued customers to a greater extent \\
\hline
\end{tabular}

*ID stands for identity number of the item 
Table 2 Profile of respondents

\begin{tabular}{|l|l|c|}
\hline Dimension & Category & Percentage (\%) \\
\hline \multirow{5}{*}{ Role } & General Director & $26.54 \%$ \\
\cline { 2 - 3 } & Chief Executive Officer & $4.08 \%$ \\
\cline { 2 - 3 } & Chief Information Officer & $63.26 \%$ \\
\cline { 2 - 3 } & Other & $6.12 \%$ \\
\hline \multirow{5}{*}{ Size of the company } & Medium & $86.5 \%$ \\
\cline { 2 - 3 } & Large & $13.5 \%$ \\
\hline & Manufacturing & $33.5 \%$ \\
\cline { 2 - 3 } & Wholesale and retail trade & $19.5 \%$ \\
\cline { 2 - 3 } & Professional, scientific and technical activities & $11.5 \%$ \\
\cline { 2 - 3 } & Construction & $6.5 \%$ \\
\cline { 2 - 3 } & Transportation and storage & $6.5 \%$ \\
\cline { 2 - 3 } & Administrative and support service activities & $6.0 \%$ \\
\cline { 2 - 3 } & Accommodation and food service activities & $4.5 \%$ \\
\cline { 2 - 3 } & Human health and social work activities & $4.0 \%$ \\
\cline { 2 - 3 } & Other sectors & $8.0 \%$ \\
\hline
\end{tabular}




\begin{tabular}{|l|l|}
\hline Construct and definition & Sources \\
\hline $\begin{array}{l}\text { Business value is defined as the transactional, strategic, transformational and } \\
\text { informational value of the big data analytics solution. Transactional value refers to the } \\
\text { degree to which the user perceives that big data analytics solutions provide operational } \\
\text { benefits. Strategic value refers to the degree of perceived benefits to the organization at } \\
\text { the strategic level. Transformational value refers to the degree of perceived changes in } \\
\text { the structure and capacity of a firm as a result of big data analytics solutions, which } \\
\text { serve as a catalyst for future benefits. Informational value refers to the degree to which } \\
\text { the user of big data analytics solutions benefits from better information. }\end{array}$ & \\
\hline $\begin{array}{l}\text { Financial performance refers to the firm's ability to improve profitability and return on } \\
\text { investment. }\end{array}$ & $\begin{array}{l}\text { (Ji-fan Ren et al. 2016; } \\
\text { Mithas et al. 2011) }\end{array}$ \\
\hline Market performance refers to the firm's ability to gain and retain customers. & (Ji-fan Ren et al. 2016) \\
\hline $\begin{array}{l}\text { Customer satisfaction refers to the firm's ability to meet or surpass customer } \\
\text { expectation. }\end{array}$ & $\begin{array}{l}\text { (Mithas et al. 2011; } \\
\text { Vorhies and Morgan } \\
\text { 2005) }\end{array}$ \\
\hline
\end{tabular}


Table 4 Descriptive and psychometric table of measurements, using ADANCO

\begin{tabular}{|c|c|c|c|c|c|c|c|}
\hline Construct & ID & Mean & SD & $\mathbf{C A}$ & AVE & Factor loading & t-values \\
\hline \multirow{4}{*}{$\begin{array}{l}\text { Transactional } \\
\text { value }\end{array}$} & TAB1 & 0.487 & 1.501 & 0.688 & 0.516 & $0.734 * * *$ & 5.486 \\
\hline & TAB2 & 0.658 & 1.502 & & & $0.728 * * *$ & 5.860 \\
\hline & TAB3 & 0.013 & 1.553 & & & $0.697 * * *$ & 7.702 \\
\hline & TAB4 & 1.079 & 1.503 & & & $0.714 * * *$ & 7.160 \\
\hline \multirow{3}{*}{ Strategic value } & SB1 & 0.368 & 1.468 & 0.670 & 0.603 & $0.840 * * *$ & 11.845 \\
\hline & SB2 & 0.855 & 1.430 & & & $0.730 * * *$ & 6.932 \\
\hline & SB3 & 0.461 & 1.562 & & & $0.756 * * *$ & 4.512 \\
\hline \multirow{4}{*}{$\begin{array}{l}\text { Transformational } \\
\text { value }\end{array}$} & TFB1 & 0.513 & 1.527 & 0.770 & 0.594 & $0.815 * * *$ & 10.477 \\
\hline & TFB2 & 0.592 & 1.593 & & & $0.771 * * *$ & 10.294 \\
\hline & TFB3 & 0.908 & 1.298 & & & $0.815 * * *$ & 10.772 \\
\hline & TFB4 & 1.013 & 1.227 & & & $0.672 * * *$ & 6.412 \\
\hline \multirow{3}{*}{$\begin{array}{l}\text { Informational } \\
\text { value }\end{array}$} & IB1 & 0.908 & 1.435 & 0.650 & 0.585 & $0.714 * * *$ & 5.499 \\
\hline & IB2 & 1.487 & 1.291 & & & $0.825 * * *$ & 9.576 \\
\hline & IB3 & 1.211 & 1.225 & & & $0.751 * * *$ & 4.858 \\
\hline \multirow{3}{*}{$\begin{array}{l}\text { Financial } \\
\text { performance }\end{array}$} & FP1 & 0.211 & 1.389 & 0.721 & 0.641 & $0.773 * * *$ & 17.494 \\
\hline & FP2 & 0.553 & 1.389 & & & $0.832 * * *$ & 14.319 \\
\hline & FP3 & 0.724 & 1.218 & & & $0.795 * * *$ & 7.686 \\
\hline \multirow{4}{*}{$\begin{array}{l}\text { Market } \\
\text { performance }\end{array}$} & MP1 & 0.355 & 1.512 & 0.810 & 0.637 & $0.850 * * *$ & 18.180 \\
\hline & MP2 & 0.303 & 1.442 & & & $0.774 * * *$ & 11.222 \\
\hline & MP3 & 0.566 & 1.360 & & & $0.689 * * *$ & 7.229 \\
\hline & MP4 & 0.289 & 1.422 & & & $0.867 * * *$ & 24.238 \\
\hline \multirow{4}{*}{$\begin{array}{l}\text { Customer } \\
\text { satisfaction }\end{array}$} & CS1 & 0.618 & 1.451 & 0.839 & 0.676 & $0.880 * * *$ & 27.639 \\
\hline & CS2 & 0.513 & 1.562 & & & $0.814^{* * *}$ & 18.049 \\
\hline & CS3 & 0.566 & 1.455 & 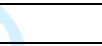 & & $0.848 * * *$ & 8.568 \\
\hline & CS4 & 0.513 & 1.419 & $\bar{x}$ & & $0.739 * * *$ & 7.514 \\
\hline
\end{tabular}

Note: $\mathrm{SD}=$ standard deviation; $\mathrm{CA}=$ Cronbach's alpha; $\mathrm{AVE}=$ average variance extracted; ${ }^{* * *} \mathrm{p}<0.001$. 
Table 5 Correlation matrix of the measured scales for discriminant validity evaluation and square roots of the average variance extracted as diagonal elements, using ADANCO

\begin{tabular}{|l|l|c|c|c|c|c|c|c|}
\hline No. & Variable & $\mathbf{1}$ & $\mathbf{2}$ & $\mathbf{3}$ & $\mathbf{4}$ & $\mathbf{5}$ & $\mathbf{6}$ & $\mathbf{7}$ \\
\hline $\mathbf{1}$ & Financial performance & 0.800 & & & & & & \\
\hline $\mathbf{2}$ & Market performance & 0.423 & 0.798 & & & & & \\
\hline $\mathbf{3}$ & Customer satisfaction & 0.547 & 0.571 & 0.822 & & & & \\
$\mathbf{4}$ & Transactional value & 0.198 & 0.217 & 0.148 & 0.718 & & &
\end{tabular}


Table 6 Results on the outcome variables, using PROCESS

\begin{tabular}{|l|c|c|c|c|c|c|}
\hline Outcome: market performance & Coeff. & SE & t & p & LLCI & ULCI \\
\hline Constant & -0.369 & 0.124 & -2.964 & 0.004 & -0.617 & -0.121 \\
\hline Business value & 0.971 & 0.109 & 8.899 & 0.000 & 0.754 & 1.188 \\
\hline R & $71.90 \%$ & & & & & \\
\hline F & $79.194^{* * *}$ & & & & & \\
\hline Outcome: customer satisfaction & & & & & & \\
\hline Constant & -0.131 & 0.147 & -0.887 & 0.378 & -0.425 & 0.163 \\
\hline Business value & 0.888 & 0.129 & 6.866 & 0.000 & 0.630 & 1.146 \\
\hline R & $62.38 \%$ & & & & & \\
\hline F & $47.139 * * *$ & & & & & \\
\hline Outcome: Financial performance & & & & & & \\
\hline Constant & -0.054 & 0.111 & -0.482 & 0.631 & -0.276 & 0.168 \\
\hline Market performance & 0.039 & 0.119 & 0.331 & 0.742 & -0.198 & 0.277 \\
\hline Customer satisfaction & 0.486 & 0.100 & 4.844 & 0.000 & 0.286 & 0.686 \\
\hline Business value & 0.345 & 0.134 & 2.576 & 0.012 & 0.078 & 0.612 \\
\hline R & $78.64 \%$ & & & & & \\
\hline F & $38.909^{* * *}$ & & & & & \\
\hline
\end{tabular}

Note: SE = standard error; LLCI and ULCI = lower and upper level for confidence level; $t=t$-statistic; $p=p$-value; $* * *$ p-value $<0.1 \%$ 
Table 7 Results of the direct and indirect effects, using PROCESS

\begin{tabular}{|c|c|c|c|c|c|c|}
\hline $\begin{array}{l}\text { Direct effect of Business Value } \\
\text { on Financial Performance }\end{array}$ & Effect & SE & LLCI & ULCI & $\mathbf{t}$ & $\mathbf{p}$ \\
\hline & 0.345 & 0.134 & 0.078 & 0.612 & 2.576 & 0.012 \\
\hline $\begin{array}{l}\text { Indirect effect of Business } \\
\text { Value on Financial } \\
\text { Performance }\end{array}$ & Effect & Boot SE & BootLLCI & BootULCI & & \\
\hline Total & 0.470 & 0.145 & 0.200 & 0.771 & & \\
\hline Market performance & 0.038 & 0.113 & -0.165 & 0.275 & & \\
\hline Customer satisfaction & 0.432 & 0.127 & 0.209 & 0.714 & & \\
\hline $\begin{array}{l}\text { Completely standardized } \\
\text { indirect effect of Business } \\
\text { Value on Financial } \\
\text { Performance }\end{array}$ & Effect & Boot SE & BootLLCI & BootULCI & & \\
\hline 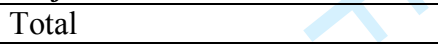 & 0.373 & 0.098 & 0.177 & 0.564 & & \\
\hline Market performance & 0.030 & 0.089 & -0.138 & 0.215 & & \\
\hline Customer satisfaction & 0.342 & 0.088 & 0.178 & 0.525 & & \\
\hline
\end{tabular}

Note: SE = standard error; LLCI and ULCI = lower and upper level for confidence level; $t=t$-statistic; $p=p$-value. 